\title{
A jobb pitvari méret és funkció noninvazív vizsgálatának módszerei és jelentőségük
}

\author{
Nógrádi Ágnes, Faludi Réka
}

Pécsi Tudományegyetem, Klinikai Központ, Szívgyógyászati Klinika, Pécs

Levelezési cím:

Dr. Nógrádi Ágnes, 7624 Pécs, Ifjúság u. 13., e-mail: noagnes@gmail.com

A szív képalkotó vizsgálatai hagyományosan a bal kamrára összpontosítottak, majd az utóbbi évtizedekben a bal pitvar, ezt követöen pedig a jobb szívfél vizsgálata is egyre inkább a tudományos kutatás fókuszába került. A korszerü képalkotó vizsgálatok - modern echokardiográfiás technikák, szív CT és MR - segítségével egyre pontosabban vizsgálható a szívüregek közül utolsóként a jobb pitvar is. A pitvarméretek egy- majd kétdimenziós vizsgálata után ma már megvalósítható a háromdimenziós kiértékelés is. A jobb időbeli felbontás révén, a pitvarfunkció különböző fázisainak differenciált vizsgálatával a korai funkcionális károsodások és a kompenzatorikus mechanizmusok is kimutathatóvá váltak. A jobb pitvari morfológia és funkció részleteinek megismerése új adatokkal gazdagíthatja a diagnosztikát, valamint a rizikó és a prognózis becslését.

Kulcsszavak: noninvazív képalkotás, jobb pitvari volumen, jobb pitvari funkció, jobb pitvari strain

\section{Non-invasive assessment of the right atrial size and function: methods and significance}

The traditional target of the cardiovascular imaging was the left ventricle. In the last decades the left atrium and the right heart also gained importance. The development of new imaging modalities such as modern echocardiographic techniques, cardiac CT and MRI made it possible to acquire more exact and detailed knowledge of the right atrium, as the last cardiac chamber to be investigated. After the one- and two-dimensional evaluation of the right atrial size, three-dimensional volume evaluation has become also possible. Better temporal resolution enables the differentiated assessment of the phases of right atrial function, providing more information on early functional impairment and compensatory mechanisms. The detailed knowledge of right atrial morphology and function allows for more exact diagnosis, risk assessment and prognostic evaluation.

Keywords: noninvasive imaging, right atrial volume, right atrial function, right atrial strain

\section{Bevezetés}

Régen elmúlt már az a korszak, amikor a jobb szívfél szerepét elhanyagolhatónak vélték a szív müködésében. Napjainkban a jobb kamra $(1,2)$ mellett a jobb pitvar (JP) müködése is egyre inkább a vizsgálódások célpontjává válik $(3,4)$. A korszerủ képalkotó módszerek - modern echokardiográfiás technikák, CT, MR segítségével egyre több diagnosztikus és prognosztikus jelentőségű információ nyerhető erről az üregről is.
A bal pitvar méretének és funkciójának különböző kórképekben bekövetkező változásait már kiterjedten vizsgálták, és ezek az adatok nagymértékben hozzájárultak a balszívfél-elégtelenség patofiziológiájának megértéséhez $(5,6)$. A különböző képalkotó eljárások fejlődésével párhuzamosan egyre több adat áll rendelkezésre a JP-i mechanikával kapcsolatban is, amelyek figyelmet érdemelnek. Így jelen munkánk célja, hogy áttekintsük a JP-i méret- és funkció vizsgálatára szolgáló noninvazív képalkotó módszereket és azok klinikai jelentőségét. 


\section{Élettani megfontolások}

Régóta ismert, hogy a pitvarok müködésében három fázis különíthető el a szívciklus során:

- zárt atrioventrikuláris (AV) billentyűk mellett a pitvar rezervoárként müködik, befogadva a vénákon beáramló vért (rezervoár fázis).

- Az AV-billentyük megnyílása után a kamrai relaxáció során a pitvar energiabefektetéssel nem járó, úgynevezett konduit (átvezető) szerepet tölt be a kamra passziv telődésében (konduit fázis).

- Végül a pitvar aktív kontrakciója booster (rásegítő) pumpaként járul hozzá a kamrai telődéshez (kontraktilis fázis) $(3,5,7)$.

A pitvar és kamra szoros kapcsolatban áll egymással: a rezervoár fázisban a pitvar tágulékonysága mellett meghatározó a kamrai szisztolé során az anulus elmozdulása is; a konduit fázisra a kamrai relaxáció hat vissza; a kontraktilis fázisra a pitvar aktív összehúzódásán kívül a kamrai compliance gyakorol hatást (7).

A JP feladata a jobb kamra telődésének támogatása. Ideális helyzetben a nagyvérkörböl beáramló vért nyugalomban és terhelés során is a töltőnyomás érdemi emelkedése nélkül továbbítja, megelőzendő a nagyvérköri pangást. Jobb kamrai nyomás- vagy volumenterhelés esetén a JP méretében és funkciójában bekövetkező dinamikus változások célja a perctérfogat fenntartása, és a szívelégtelenség kialakulásának késleltetése (3). Gaynor és munkatársai invazív állatkísérletek segítségével bizonyították, hogy a pulmonalis nyomás tranziens vagy permanens emelkedése első lépésben a jobb kamrai diasztolés funkció károsodásához vezet. Ennek kompenzálására a JP-i kontraktilitás emelkedik, hogy fenntartsa a jobb kamra telődését és a pertérfogatot (8). Ugyanakkor a JP a Frank-Starling-mechanizmus szerint müködik, vagyis a maximális kontrakció az optimális rosthossz mellett jön létre (7). Így a jobb kamrai diasztolés funkciózavar további progressziójával párhuzamosan ez a kompenzatorikus mechanizmus kiéghet, amikor a pitvari preload-rezerv eléri a határait, ahogy ez a bal pitvarral kapcsolatban már leírásra került (9).

\section{A jobb pitvar méretének meghatározása}

A pitvar remodelling késői, de relatíve könnyen dokumentálható megnyilvánulása a pitvar méretének megnövekedése $(3,6)$.

A klinikumban a mai napig széles körben alkalmazzuk a lineáris átmérők mérését, annak ellenére, hogy az irodalomban a JP-i átmérők reprodukálhatóságáról vagy prognosztikus szerepéről kevés adat áll rendelkezésre. Az átmérőket csúcsi 4-üregű nézetből mérjük: a hoszszanti átméröt a tricuspidalis anulus közepétöl a pitvar bázisának közepéig, a pitvari septummal párhuzamosan, míg a keresztátmérőt erre merőlegesen, középmagasságban, a szabad fal és a pitvari septum között.
(Normálértékek: hosszanti átmérő $<53 \mathrm{~mm}$, keresztátmérő $<44 \mathrm{~mm}$ ) (10). A legújabb ajánlás nemek szerinti, testfelszínre normalizált normálértékeket is megad (11). Igazolt klinikai haszna a JP-i area és térfogat mérésének van, bár ezek technikailag nagyobb kihívást jelentő, időigényesebb módszerek $(10,11)$. Az area mérése planimetriával történik, szintén csúcsi 4-üregü nézetből. A mért területből ki kell zárni a tricuspidalis billentyű záródási háromszögét, a vena cava superior és inferior beszájadzását és a pitvari fülcsét. A jobb pitvari area normálértéke $<18 \mathrm{~cm}^{2}$. A jelenlegi ajánlás szerint az area mérése preferálandó a lineáris dimenziókkal szemben (10).

Bár a JP esetében csak egy síkból lehet az areát mér$\mathrm{ni}$, area-length módszerrel vagy disk summation technikával mégis becsülhetö a JP-i volumen. Ennek testfelszínre indexált normálértéke férfiaknál $25 \pm 7 \mathrm{ml} / \mathrm{m}^{2}$, nők esetén $\left.21 \pm 6 \mathrm{ml} / \mathrm{m}^{2}\right)(11,12)$.

A szív-CT és -MR egyaránt háromdimenziós képet képes alkotni a szív üregeiről, így nincs szükség geometriai feltételezésekre a JP-i volumen meghatározásához. Több vizsgálat történt az echokardiográfiás és a $C T$-vel vagy MR-rel nyert adatok összehasonlítására. Általában jó, vagy elfogadható korrelációkat igazoltak, bár a $2 \mathrm{D}$-echokardiográfiás (2DE) módszerek alulbecsülték a JP-i volument $(12,13)$.

A 3D-echokardiográfia (3DE) megjelenése lehetőséget nyitott arra, hogy az ionizáló sugárzás káros hatása nélkül, az echokardiográfiás laborban is valós térfogatadatokat nyerhessünk a szív komplex alakú üregeiröl (3). A 3DE-vel nyert JP-i volumenértékek nagyobbak, mint a 2DE-adatok $(14,15)$, ám a CT- és MR-adatokkal összehasonlítva a $3 \mathrm{DE}$ is szignifikánsan alulmér (13, 16, 17).

\section{A jobb pitvar méretének klinikai jelentősége}

A maximális JP-i area vagy a jobb és bal pitvari area aránya számos klinikai szituációban bizonyult a kedvezőtlen klinikai kimenetel vagy a mortalitás prediktorának, így csökkent ejekciós frakcióval járó szívelégtelenségben (HFrEF) (18), Eisenmenger-szindrómában (19), akut tüdőembóliában (20) és primer pulmonalis artériás hipertóniás (PAH) betegekben (21). A JP-i area a betegek funkcionális kapacitásának is jó mutatója. $L i-$ mongelli és munkatársai hipertrófiás cardiomyopathiás betegekben írták le ezt az korrelációt (22), míg munkacsoportunk krónikus obstruktív tüdőbetegségben szenvedők esetében figyelt meg hasonló összefüggést (23). A terápia hatékonyságát is igazolhatja a JP-i area követéses vizsgálata: Marra és munkatársai krónikus trombembóliás pulmonalis hipertóniás betegekben írták le a JP-i area csökkenését riociguat kezelés hatására (24). Pitvari sövényhiány zárását követően pedig a jobb és bal pitvari area arányának normalizálódását írták le (25). 
1. TÁBLÁZAT. A pitvari funkció fázisait jellemző dinamikus volumenparaméterek és kiszámításuk

\begin{tabular}{|c|c|c|}
\hline \multirow[t]{3}{*}{$\begin{array}{l}\text { Rezervoár } \\
\text { funkció }\end{array}$} & $\begin{array}{l}\text { Teljes ürülési } \\
\text { volumen }\end{array}$ & $\mathrm{V}_{\mathrm{te}}=\mathrm{V}_{\max }-\mathrm{V}_{\min }$ \\
\hline & Teljes ürülési frakció & $\mathrm{TEF}=\mathrm{V}_{\mathrm{te}} / \mathrm{V}_{\max } \times 100(\%)$ \\
\hline & Expanziós index & $\mathrm{El}=\mathrm{V}_{\mathrm{te}} / \mathrm{V}_{\min } \times 100(\%)$ \\
\hline \multirow{2}{*}{$\begin{array}{l}\text { Conduit } \\
\text { funkció }\end{array}$} & Passzív ürülési volumen & $\mathrm{V}_{\mathrm{pe}}=\mathrm{V}_{\max }-\mathrm{V}_{\mathrm{p}}$ \\
\hline & Passzív ürülési frakció & $\mathrm{PEF}=\mathrm{V}_{\mathrm{pe}} / \mathrm{V}_{\max } \times 100(\%)$ \\
\hline \multirow[t]{2}{*}{$\begin{array}{l}\text { Kontraktilis } \\
\text { funkció }\end{array}$} & $\begin{array}{l}\text { Aktív ürülési } \\
\text { volumen }\end{array}$ & $\mathrm{V}_{\mathrm{ae}}=\mathrm{V}_{\mathrm{p}}-\mathrm{V}_{\min }$ \\
\hline & Aktív ürülési frakció & $\mathrm{AEF}=\mathrm{V}_{\mathrm{ae}} / \mathrm{N}_{\mathrm{p}} \times 100(\%)$ \\
\hline
\end{tabular}

AEF: aktív ürülési frakció; PEF: passzív ürülési frakció; TEF: teljes ürülési frakció; $V_{\text {te }}$ : teljes ürülési volumen, $V_{\mathrm{pe}}$ : passzív ürülési volumen; $\mathrm{V}_{\mathrm{ae}}$ : aktív ürülési volumen; $V_{\text {max }}$ : maximális pitvari volumen; $V_{\text {min }}$ : minimális pitvari volumen; $V_{p}$ : pitvari kontrakció kezdetén mért pitvari volumen; El: expanziós index

A maximális JP-i volumen, illetve testfelszínre indexált változata (JPVI) klinikai jelentőségét számos kórképben írták le. HFrEF-betegekben a JPVI összefüggést mutatott a betegek funkcionális állapotával, valamint a mortalitás és egyéb adverz események független prediktorának bizonyult (26-30). Hasonló eredmények születtek PAH-populációban is $(31,32)$.

Luong és munkatársai eredményei alapján a JPVI a pitvarfibrilláció visszatérésének erősebb prediktora, mint a bal pitvari volumenindex (BPVI) (33). A JPVI és BPVI aránya is előre jelezte a pitvarfibrilláció kiújulását pulmonalis vénaizoláción átesett betegekben (34). A JPVI Fallot-tetralógia miatt operált betegekben a szupraventrikuláris aritmiák prediktorának bizonyult (35).

\section{A jobb pitvari fázikus funkció vizsgálata és ennek klinikai jelentősége: volumetrikus megko̊zelítés}

Még a pitvari volumen megnövekedése előtt jelentkezik a pitvar funkciójának megváltozása, ami a pitvar remodelling igazoltan koraibb, de nehezebben észlelhető jele $(9,36)$. A pitvari funkció vizsgálata klasszikusan a szívciklus kiemelt időpontjaiban mért pitvari volumenek segítségével történik. A maximális pitvari volumen $\left(V_{\max }\right)$ mellett szükséges a minimális pitvari volumen $\left(V_{\min }\right)$ megmérése a tricuspidalis billentyű záródásakor. A pitvari kontrakció kezdetét jellemző volumenértéket $\left(\mathrm{V}_{\mathrm{p}}\right)$ pedig az EKG-n a P-hullám kezdete definiálja (1. ábra). A statikus térfogatértékek felhasználásával számoljuk ki az az úgynevezett dinamikus térfogatértékeket, vagyis a fázisonként vizsgált ürülési volument (emptying volume, EV) és ürülési frakciót (emptying fraction, EF) $(3,15,37)$. A teljes, passzív és aktív ürülési volumenek és frakciók a JP-rezervoár, konduit és kontraktilis funkcióját tükrözik. A rezervoárfunkció jellemzésére a teljes ürülési frakció (TEF) mellett az expanziós index (EI) is használatos, amely a pitvari telődés mértékét a minimális térfogathoz viszonyítja. A kiszámításukra szolgáló képleteket az 1. táblázat foglalja össze.

A hagyományos 2DE-módszerrel a fázisos JP-i volumenértékek vizsgálata nehézkes és pontatlan volt, ezért elsősorban CT-t és MR-t, majd újabban 3DE-t használnak erre a célra.

A bemutatott volumetrikus megközelítést használva Willens és munkatársai megállapították, hogy egészséges alanyokban az életkor hatással van a JP-i paszszív és aktív ürülési frakció (PEF, illetve AEF) arányára: a PEF idősebbeknél csökkent, míg az AEF idősekben nőtt, ami a diasztolés funkció életkorral összefüggő hanyatlásának felel meg (37).

A módszert számos munkacsoport használta a JP funkciójának vizsgálatára PAH-ban: Darsaklis és munkatársai adatai alapján a TEF, míg Brunner és munkatársai szerint a TEF- és az AEF-érték erőteljes inverz asszociációt mutat a mortalitással ebben a kórképben (38, 39). A Willens és munkatársai által vizsgált PAH-betegekben az emelkedett pitvari volumenek mellett csökkent PEF- és emelkedett AEF-érték volt látható (37). Más adatok szerint a legrosszabb funkcionális állapotú, károsodott jobbkamra-funkciójú PAH-betegek alcsoportjában a TEF és AEF is károsodott volt, míg a jó jobbkamra-funkciójú alcsoportban emelkedett AEF-értékeket találtak $(40,41)$.

Szívelégtelen populációban Proplesch és munkatársai adatai alapján a TEF szignifikánsan csökkent volt, és az emelkedett JPVI mellett ez is a halálozás és a hospitalizáció magasabb kockázatával járt (29).

Inferior miokardiális infarktushoz társuló jobb kamrai érintettség esetén 3DE-vizsgálattal a JP-i volumenértékek emelkedettek, a PEF pedig csökkent volt. A maximális JPVI volt képes a leghatékonyabban azonosítani a jobb kamrai infarktust elszenvedett alcsoportot (42).

\section{A strain szerepe a jobb pitvari fázikus funkció vizsgállatában}

A speckle tracking alapú strain-technika új fejezetet nyitott a JP-i mechanika vizsgálatában is. Teljesen új megközelítésről van szó, amelynek segítségével rezervoár $\left(\varepsilon_{\mathrm{R}}\right)$, kontraktilis $\left(\varepsilon_{\mathrm{CT}}\right)$ és konduit $\left(\varepsilon_{\mathrm{CD}}\right)$ strainértékek határozhatók meg (1. ábra). Ezek a paraméterek alkalmasak a pitvari funkció három fázisának jellemzésére. A strain rate értékeket is használják a pitvarfunkció vizsgálatára, de egyelőre csak kutatási célokra.

A JP esetében a módszer nehézsége, hogy a bal szívféllel szemben csak egy síkból (csúcsi 4-üregü nézetből) vizsgálható; gondosan ügyelni kell a nézet optimalizálására (jobb kamrára/pitvarra fókuszált csúcsi 4 üreg), valamint a „foreshortening” (rövidülés) elkerülésére (4). A strain-technika bevezetésekor a szoftvert a bal kamrára fejlesztették ki, a további szívüregek számára dedikált szoftverek korlátozottan elérhetők. A normálértékek meghatározását nehezíti, hogy jelentős kü- 


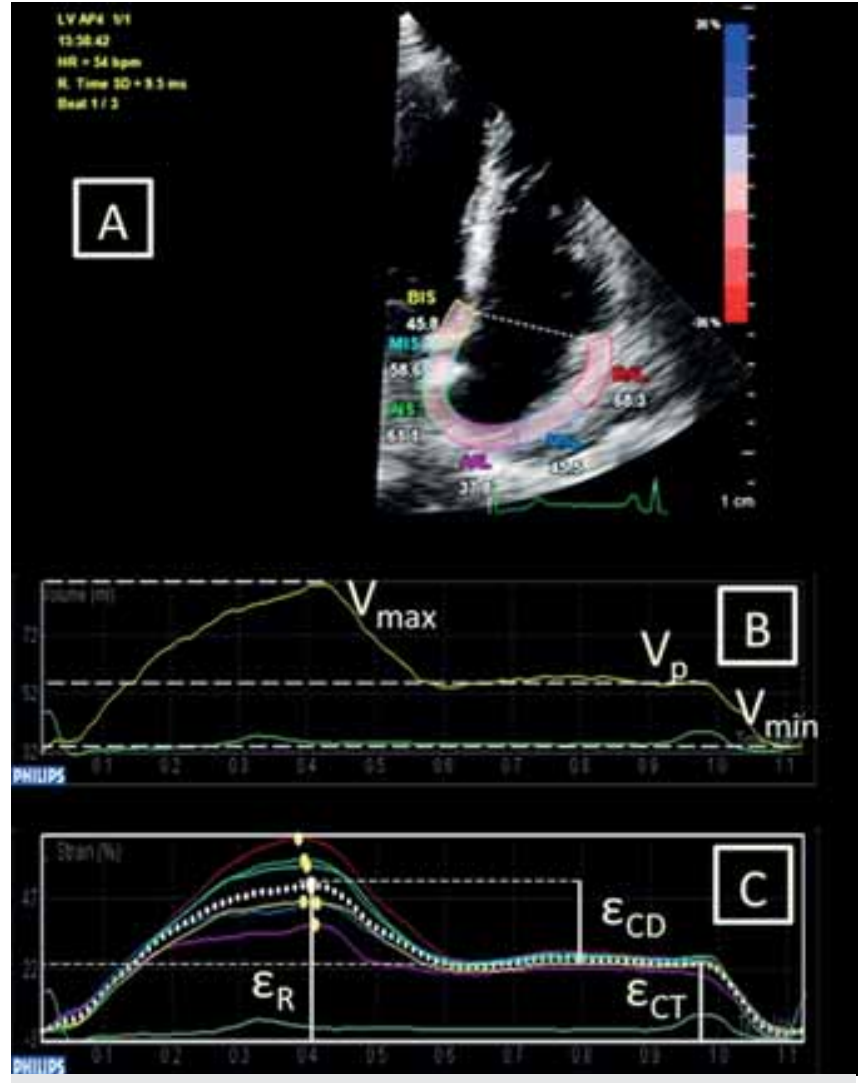

1. ÁBRA. A jobb pitvar speckle tracking echokardiográfiás vizsgálata. A: JK-ra fókuszált csúcsi 4-üregű képen a jobb pitvar kijelölt kontúrja (region of interest). B: a szoftver által generált jobb pitvari volumengörbe a 3 fázisra jellemző volumenértékekkel. C: jobb pitvari strain görbe. $\left(\mathrm{V}_{\mathrm{max}}\right.$ : maximális jobb pitvari térfogat; $V_{\mathrm{p}}$ : jobb pitvari kontrakció kezdetén mért térfogat; $\mathrm{V}_{\min }$ : minimális jobb pitvari térfogat; $\varepsilon_{\mathrm{R}}$ : rezervoár strain; $\varepsilon_{\mathrm{CD}}$ : konduit strain; $\varepsilon_{\mathrm{CT}}$ : kontraktilis strain)

lönbségek lehetnek a különböző gyártók szoftvereivel nyert eredmények között. Befolyásolja a strain értékét az is, hogy a referenciapont a QRS-, vagy a P-hullám kezdete. Ennek ellenére a szakirodalom számos vizsgálatról számol be, amelyek a JP-i strain vizsgálatát megvalósíthatónak és megbízhatónak ítélik (15, 43).

A JP-i strain klinikai jelentőségéről számos kórképben áll már rendelkezésre irodalmi adat: PAH-os populációban számos vizsgálat igazolt korrelációt a JP-i strain és az invazívan mért hemodinamikai paraméterek között: negatív asszociációt mutattak ki a jobb pitvari nyomással (44-48) és a pulmonalis vaszkuláris rezisztenciával $(46,49)$, illetve pozitív összefüggést a cardiac indexszel, stroke-volumennel vagy a perctérfogattal $(46,47)$. A betegek funkcionális állapotával is összefüggést mutat a $\varepsilon_{R}(49,50)$, ezen felül a kedvezőtlen kimenetel, illetve a mortalitás prediktorának bizonyult számos tanulmányban $(44,45,50,51)$. A PAHos betegre jellemző tágult JP és csökkent $\varepsilon_{R}$ látható a 2. ábrán. Bai és munkatársai kötőszöveti betegséghez társuló PAH-ban igazolták a JP-i kontraktilis funkció kompenzatorikus szerepét: a JP-i késő diasztolés strain rate az eseménymentes, jó állapotú PAH-betegekben emelkedett, míg az adverz eseményt mutató alcsoportban károsodott volt az egészséges kontrollcsoporthoz képest (50). HFrEF-es betegekben is kimutatható volt a JP-i $\varepsilon_{R}$ károsodása. $\varepsilon_{R}$ több vizsgálatban $(43,51)$ korrelációt mutatott a pulmonalis nyomással balszívfél-elégtelenségben, és hatékonyan volt képes jelezni a magas pulmonalis nyomással bíró betegeket (43).

Jain és munkatársai a JP-i funkció volumetrikus és strain paramétereit együtt vizsgálták HFrEF-ben, megtartott szisztolés funkciójú szívelégtelenségben (HFpEF) szenvedő betegekben és nem szívelégtelen kontrollpopulációban. A JP-i funkció súlyosabb károsodása igazolódott HFrEF-ben, mint a HFpEF-betegekben. A $\varepsilon_{R}$, $\varepsilon_{\mathrm{CD}}$ és az El-értékek bizonyultak az összhalálozás prediktorainak (52).

A bal szívfélben már igazolást nyert, hogy a bal pitvari funkció volumetrikusan mért és strainparaméterei hasonló viselkedést mutatnak a diasztolés funkciózavar különböző stádiumaiban, ám a strainértékek diszkriminatív ereje nagyobb $(9,53,54)$. Hasonló eredmények még nem születtek a jobb szívfélben, de igazolt, hogy a fázisos JP-i volumenértékek jó korrelációt mutatnak a megfelelő JP-i strainértékekkel (55).

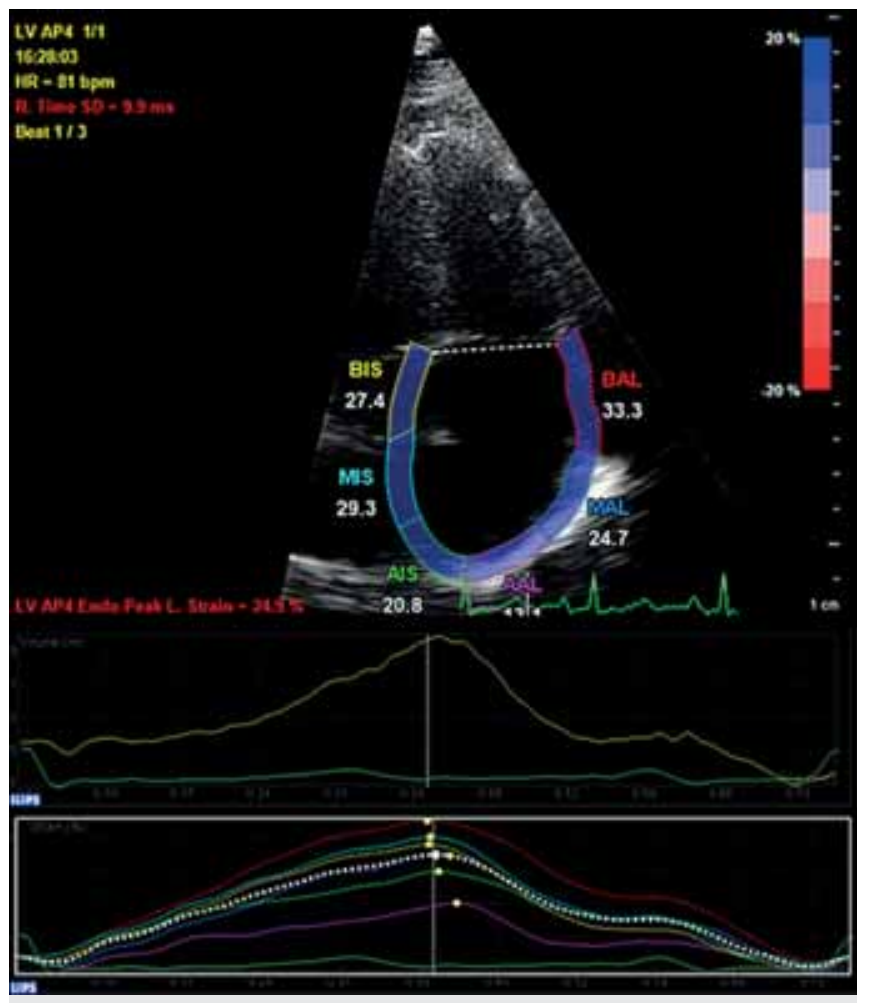

2. ÁBRA. Pulmonalis artériás hipertóniás beteg jellegzetes jobb pitvari strain és volumengörbéje. Tágabb jobb pitvar, csökkent $\varepsilon_{R}$ figyelhető meg 


\section{Jobb pitvari stiffness}

A pitvari stiffness értéke azt fejezi ki, hogy a pitvar térfogatának egységnyi emeléséhez mekkora pitvari nyomásemelkedés szükséges. Noninvazív módon az E/e' arány és a $\varepsilon_{R}$ hányadosaként írható le (56). A bal pitvari stiffness jól korrelál a bal kamrai töltőnyomással és kiváló kiegészítő paraméterként szerepelhet a HFpEF differenciáldiagnosztikájában $(56,57)$.

A JP-i stiffness használhatóságát elsőként Teixeira és munkatársai vizsgálták, akik igazolták, hogy szívelégtelen betegekben korrelál a tricuspidalis regurgitáció méretével (58). Az élsportolókban megfigyelhető fiziológiás adaptáció és a patológiás változások elkülönítése a sportkardiológia fontos kutatási területe. Élsportolókban többek között megfigyelhető a JP-i area és JPVI emelkedése, valamint alacsonyabb $\varepsilon_{R}$ és $\varepsilon_{C T}$-értékeket írtak le, azonban a $\varepsilon_{R} / \varepsilon_{\mathrm{CT}}$-arány és JP-i stiffness nem különbözik a kontrollpopulációtól $(59,60)$.

Saját vizsgálatainkkal normális JPVI-értékekkel bíró sclerodermás populációban mutattuk ki az $\varepsilon_{R}$ és $\varepsilon_{C D}$ csökkenését valamint a JP-i stiffness emelkedését egészséges kontrollpopulációval összehasonlítva. A JP-i stiffness a rossz funkcionális állapot kiváló prediktorának bizonyult (36).

\section{Következtetések}

A JP méretének és funkciójának vizsgálatát az utóbbi időben forradalmasította a modern noninvazív képalkotó modalitások fejlődése. A JP vizsgálatától nemcsak azon kórképek jobb megértéséhez remélhetünk segítséget, amelyekben a jobb szívfél terheltsége dominál, hanem balszívfél-elégtelenség különböző formáiban is javíthat a diagnosztikus pontosságon. A JP-i mechanika korrelációt mutat a betegek funkcionális állapotával és a kedvezőtlen prognózist is hatékonyan jelzi előre. Ha ezek a modern módszerek a klinikai gyakorlat részévé válnak, hozzájárulhatnak a betegek hatékonyabb diagnosztikájához és követéséhez.

\section{Nyilatkozat}

A szerzők kijelentik, hogy a tanulmány megírásával kapcsolatban nem áll fenn velük szemben pénzügyi vagy egyéb lényeges összeütközés, összeférhetetlenségi ok, amelyek befolyásolhatják a tanulmányban bemutatott eredményeket, az abból levont következtetéseket vagy azok értelmezését.

\section{Irodalom}

1. Rigolin VH, Robiolio PA, Wilson JS, et al. The forgotten chamber: The importance of the right ventricle. Cathet Cardiovasc Diagn 1995; 35(1): 18-28. DOI: 10.1002/ccd.1810350105

2. Karas MG, Kizer JR. Echocardiographic assessment of the right ventricle and associated hemodynamics. Prog Cardiovasc Dis 2012; 55(2): 144-60. DOI: 10.1016/j.pcad.2012.07.011

3. Tadic M. The right atrium, a forgotten cardiac chamber: An upda- ted review of multimodality imaging. J Clin Ultrasound 2015; 43 (6): 335-45. DOI: 10.1002/jcu.22261

4. Badano LP, Kolias TJ, Muraru D, et al. Standardization of left atrial, right ventricular, and right atrial deformation imaging using two-dimensional speckle tracking echocardiography: A consensus document of the EACVI/ASE/Industry Task Force to standardize deformation imaging. Eur Heart J Cardiovasc Imaging 2018; 19(6): 591-600. DOI: 10.1093/ehjci/jey042

5. Hoit BD. Left atrial size and function: Role in prognosis. J Am Coll Cardiol 2014; 63(6): 493-505. DOI: 10.1016/j.jacc.2013.10.055

6. Douglas PS. The left atrium: a biomarker of chronic diastolic dysfunction and cardiovascular disease risk. J Am Coll Cardiol 2003; 42(7): 1206-7. DOI: 10.1016/S0735-1097(03)00956-2

7. Rai ABS, Lima E, Munir F, et al. Speckle tracking echocardiography of the right atrium: The neglected chamber. Clin Cardiol 2015; 38(11): 692-7. DOI: $10.1002 / \mathrm{clc} .22438$

8. Gaynor SL, Maniar HS, Bloch JB, et al. Right atrial and ventricular adaptation to chronic right ventricular pressure overload. Circulation 2005; 112(9 Suppl): 212-8. DOI: 10.1161/CIRCULATIONAHA.104.517789

9. Porpáczy A, Nógrádi Á, Kehl D, et al. Impairment of left atrial mechanics is an early sign of myocardial involvement in systemic sclerosis. J Card Fail 2018; 24 (4): 234-42. DOI: 1016/j.cardfail.2018.02.012 10. Rudski LG, Lai WW, Afilalo J, et al. Guidelines for the echocardiographic assessment of the right heart in adults: a report from the American Society of Echocardiography endorsed by the European Association of Echocardiography, a registered branch of the European Society of Cardiology, and the Canadian Society of Echocardiography. J Am Soc Echocardiogr 2010; 23(7): 685-8. DOI: 10.1016/j. echo.2010.05.010

11. Lang RM, Badano LP, Mor-Avi V, et al. Recommendations for cardiac chamber quantification by echocardiography in adults: an update from the American Society of Echocardiography and the European Association of Cardiovascular Imaging. J Am Soc Echocardiogr 2015; 28(1): 1-39 e14. DOI: 10.1016/j.echo.2014.10.003

12. Ebtia M, Murphy D, Gin K et al. Best method for right atrial volume assessment by two-dimensional echocardiography: Validation with magnetic resonance imaging. Echocardiography 2015; 32(5): 734-9. DOI: $10.1111 /$ echo.12735

13. Takahashi A, Funabashi N, Kataoka A, et al. Quantitative evaluation of right atrial volume and right atrial emptying fraction by 320-slice computed tomography compared with three-dimensional echocardiography. Int J Cardiol 2011; 146 (1): 96-9. DOI: 10.1016/j. ijcard.2010.05.069

14. Moreno J, De Isla LP, Campos $N$, et al. Right atrial indexed volume in healthy adult population: Reference values for two-dimensional and three-dimensional echocardiographic measurements. Echocardiography 2013 ; 30(6): 667-71. DOI: 10.1111/echo.12121

15. Peluso D, Badano LP, Muraru D, et al. Right atrial size and function assessed with three-dimensional and speckle-tracking echocardiography in 200 healthy volunteers. Eur Heart J Cardiovasc Imaging 2013; 14(11): 1106-14. DOI: 10.1093/ehjci/jet024

16. Müller $H$, Carballo $D$, Dos Santos $S$, et al. Measurement of right atrial volumes: Comparison of a semi-automatic algorithm of real-time 3D echocardiography with cardiac magnetic resonance imaging. Int J Cardiol 2016; 202: 621-3. DOI: 10.1016/j.ijcard.2015.09.102

17. Keller AM, Gopal AS, King DL. Left and right atrial volume by freehand three-dimensional echocardiography: In vivo validation using magnetic resonance imaging. Eur J Echocardiogr 2000; 1(1): 55-65. DOI: 10.1053/euje.2000.0010

18. Almodares $Q$, Wallentin Guron $C$, Thurin A, et al. Larger right atrium than left atrium is associated with all-cause mortality in elderly patients with heart failure. Echocardiography 2017; 34(5): 662-7. DOI: 10.1111/echo.13500

19. Moceri P, Dimopoulos K, Liodakis E, et al. Echocardiographic predictors of outcome in Eisenmenger syndrome. Circulation 2012; 126(12): 1461-8. DOI: 10.1161/CIRCULATIONAHA.112.091421

20. Chow V, Ng ACC, Chung $\mathrm{T}$, et al. Right atrial to left atrial area ratio on early echocardiography predicts long-term survival after acute pulmonary embolism. Cardiovasc Ultrasound 2013; 11(1): 17. DOI: 10.1186/1476-7120-11-17

21. Fukuda $Y$, Tanaka $H$, Motoji $Y$, et al. Utility of combining assessment of right ventricular function and right atrial remodeling as a prognostic factor for patients with pulmonary hypertension. Int J Cardiovasc Imaging 2014; 30(7): 1269-77. DOI: 10.1007/s10554-014-0460-6

22. Limongelli G, Masarone D, Frisso G, et al. Clinical and genetic 
characterization of patients with hypertrophic cardiomyopathy and right atrial enlargement. J Cardiovasc Med 2017; 18(4): 249-54. DOI: 10.2459/JCM.0000000000000361

23. Faludi $R$, Hajdu $M$, Vértes $V$, et al. Diastolic dysfunction is a contributing factor to exercise intolerance in COPD. 2016; 13(3): 345-51. doi: $10.3109 / 15412555.2015 .1084614$

24. Marra AM, Egenlauf $B$, Ehlken $N$, et al. Change of right heart size and function by long-term therapy with riociguat in patients with pulmonary arterial hypertension and chronic thromboembolic pulmonary hypertension. Int J Cardiol 2015; 195: 19-26. DOI: 10.1016/j.ijcard.2015.05.105

25. Kelly NFA, Walters DL, Hourigan LA, et al. The relative atrial index (RAI) - A novel, simple, reliable, and robust transthoracic echocardiographic indicator of atrial defects. J Am Soc Echocardiogr 2010; 23(3): 275-81. DOI: 10.1016/j.echo.2009.11.014

26. Altes A, Appert L, Delelis F, et al. Impact of increased right atrial size on long-term mortality in patients with heart failure receiving cardiac resynchronization therapy. Am J Cardiol 2019; 123(6): 936-41. DOI: 10.1016/j.amjcard.2018.12.015

27. Sallach JA, Tang WHW, Borowski AG, et al. Right atrial volume index in chronic systolic heart failure and prognosis. JACC Cardiovasc Imaging 2009; 2(5): 527-34. DOI: 10.1016/j.jcmg.2009.01.012

28. Ivanov A, Mohamed A, Asfour A, et al. Right atrial volume by cardiovascular magnetic resonance predicts mortality in patients with heart failure with reduced ejection fraction. PLoS One 2017; 12(4): e0173245. DOI: 10.1371/journal.pone.0173245

29. Proplesch $M$, Merz AA, Claggett $B L$, et al. Right atrial structure and function in patients with hypertension and with chronic heart failure. Echocardiography 2018; 35(7): 905-14. DOI: 10.1111/echo.13876 30. Darahim K. Usefulness of right atrial volume index in predicting outcome in chronic systolic heart failure. J Saudi Heart Assoc 2014; 26(2): 73-9. DOI: 10.1016/j.jsha.2013.09.002

31. Mysore MM, Bilchick KC, Ababio P, et al. Right atrial to left atrial volume index ratio is associated with increased mortality in patients with pulmonary hypertension. Echocardiography 2018; 35(11): 172935. DOI: $10.1111 /$ echo.14149

32. Bredfelt A, Rådegran $G$, Hesselstrand $R$, et al. Increased right atrial volume measured with cardiac magnetic resonance is associated with worse clinical outcome in patients with pre-capillary pulmonary hypertension. ESC Heart Fail 2018; 5(5): 864-75. DOI: 10.1002/ ehf2.12304

33. Luong $\mathrm{C}$, Thompson DJS, Bennett $\mathrm{M}$, et al. Right atrial volume is superior to left atrial volume for prediction of atrial fibrillation recurrence after direct current cardioversion. Can J Cardiol 2015; 31(1): 29-35. DOI: 10.1016/j.cjca.2014.10.009

34. Sasaki T, Nakamura K, Naito $S$, et al. The right to left atrial volume ratio predicts outcomes after circumferential pulmonary vein isolation of longstanding persistent atrial fibrillation. Pacing Clin Electrophysiol 2016; 39(11): 1181-90. DOI: 10.1111/pace.12953

35. Sohns JM, Rosenberg C, Zapf A, et al. Right atrial volume is increased in corrected tetralogy of Fallot and correlates with the incidence of supraventricular arrhythmia: A CMR study. Pediatr Cardiol 2015; 36(6): 1239-47. DOI: 10.1007/s00246-015-1152-2

36. Nógrádi Á, Porpáczy A, Porcsa L, et al. Relation of right atrial mechanics to functional capacity in patients with systemic sclerosis. Am J Cardiol 2018; 122(7): 1249-54. DOI: 10.1016/j.amjcard.2018.06.021 37. Willens HJ, Fertel DP, Qin J, et al. Effects of age and pulmonary arterial hypertension on the different phases of right atrial function. Int J Cardiovasc Imaging 2008; 24(7): 703-10. DOI: 10.1007/s10554008-9306-4

38. Darsaklis K, Dickson ME, Cornwell W, et al. Right atrial emptying fraction non-invasively predicts mortality in pulmonary hypertension. Int J Cardiovasc Imaging 2016; 32(7): 1121-30. DOI: 10.1007/s10554016-0883-3

39. Brunner NW, Haddad F, Kobayashi Y, et al. Prognostic utility of right atrial emptying fractions in pulmonary arterial hypertension. Pulm Circ 2015; 5(3): 473-80. DOI: 10.1086/682218

40. Deng $Y$, Guo SL, Wu WF, et al. Right atrial evaluation in patients with pulmonary hypertension: A real-time 3-dimensional transthoracic echocardiographic study. J Ultrasound Med 2016; 35(1): 49-61. DOI: 10.7863/ultra.15.01028

41. Meng $\mathrm{X}$, Li Y, Li H, et al. Three-dimensional echocardiography to evaluate right atrial volume and phasic function in pulmonary hypertension. Echocardiography 2018; 35(2): 153-61. DOI: 10.7863/ ultra.15.01028

42. Kanar BG, Sunbul M, Sahin AA, et al. Evaluation of right atrial volumes and functions by real-time three-dimensional echocardiography in patients after acute inferior myocardial infarction. Echocardiography 2018; 35(11): 1806-11. DOI: 10.1111/echo.14133

43. Padeletti $M$, Cameli $M$, Lisi $M$, et al. Right atrial speckle tracking analysis as a novel noninvasive method for pulmonary hemodynamics assessment in patients with chronic systolic heart failure. Echocardiography 2011; 28(6): 658-64. DOI: 10.1111/j.15408175.2011.01413.x

44. Bhave NM, Visovatti SH, Kulick $B$, et al. Right atrial strain is predictive of clinical outcomes and invasive hemodynamic data in group 1 pulmonary arterial hypertension. Int J Cardiovasc Imaging 2017; 33 (6): 847-55. DOI: 10.1007/s10554-017-1081-7

45. Fukuda $\mathrm{Y}$, Tanaka H, Ryo-Koriyama K, et al. Comprehensive functional assessment of right-sided heart using speckle tracking strain for patients with pulmonary hypertension. Echocardiography 2016; 33(7): 1001-8. DOI: 10.1111/echo.13205

46. Sakata K, Uesugi $Y$, Isaka $A$, et al. Evaluation of right atrial function using right atrial speckle tracking analysis in patients with pulmonary artery hypertension. J Echocardiogr 2016; 14(1): 30-8. DOI: 10.1007/s12574-015-0270-4

47. D'Alto M, D'Andrea A, Di Salvo G, et al. Right atrial function and prognosis in idiopathic pulmonary arterial hypertension. Int $\mathrm{J}$ Cardiol 2017; 248: 320-5. DOI: 10.1016/j.ijcard.2017.08.047

48. Wright LM, Dwyer N, Wahi S, et al. Association with right atrial strain with right atrial pressure: an invasive validation study. Int J Cardiovasc Imaging 2018; 34(10): 1541-8. DOI: 10.1007/s10554-0181368-3

49. Saha SK, Söderberg $S$, Lindqvist $P$ et al. Association of right atrial mechanics with hemodynamics and physical capacity in patients with idiopathic pulmonary arterial hypertension: Insight from a single-center cohort in Northern Sweden. Echocardiography 2016; 33(1): 46-56. DOI: 10.1111/echo.12993

50. Bai Y, Yang J, Liu J, et al. Right atrial function for the prediction of prognosis in connective tissue disease-associated pulmonary arterial hypertension: a study with two-dimensional speckle tracking. Int J Cardiovasc Imaging 2019; 35(9): 1637-49. DOI: 10.1007/s10554019-01613-w

51. Haghighi ZO, Naderi N, Amin A, et al. Quantitative assessment of right atrial function by strain and strain rate imaging in patients with heart failure. Acta Cardiol 2011; 66(6): 737-42. DOI: 10.2143/ AC.66.6.2136957

52. Jain S, Kuriakose D, Edelstein I, et al. Right atrial phasic function in heart failure with preserved and reduced ejection fraction. JACC Cardiovasc Imaging 2019; 12(8P1): 1460-70. DOI: 10.1016/s07351097(18)32145-4

53. Brecht A, Oertelt-Prigione $S$, Seeland $U$, et al. Left atrial function in preclinical diastolic dysfunction: Two-dimensional speckle-tracking echocardiography-derived results from the BEFRI Trial. J Am Soc Echocardiogr 2016; 29(8):750-8. DOI: 10.1016/j.echo.2016.03.013

54. Freed BH, Daruwalla V, Cheng JY, et al. Prognostic utility and clinical significance of cardiac mechanics in heart failure with preserved ejection fraction: Importance of left atrial strain. Circ Cardiovasc Imaging 2016; 9(3): e003754. DOI: 10.1161/CIRCIMAGING.115.003754 55. Nógrádi Á, Porpáczy A, Molnár F, et al. Speckle tracking derived right atrial strain parameters show strong correlation with phasic volume indices in systemic sclerosis patients. Eur Heart J 2017; 38(suppl 1): ehx493. DOI: 10.1093/eurheartj/ehx493.P5236

56. Kurt M, Wang J, Torre-Amione $G$, et al. Left atrial function in diastolic heart failure. Circ Cardiovasc Imaging 2009; 2(1): 10-5. DOI: 10.1161/CIRCIMAGING.108.813071

57. Porpáczy A, Nógrádi Á, Vértes $V$, et al. Left atrial stiffness is superior to volume and strain parameters in predicting elevated NT-proBNP levels in systemic sclerosis patients. Int J Cardiovasc Imaging 2019; 35(10): 1795-802. DOI: 10.1007/s10554-019-01621-w

58. Teixeira RR, Monteiro R, Garcia JJ, et al. The relationship between tricuspid regurgitation severity and right atrial mechanics: a speckle tracking echocardiography study. Int J Cardiovasc Imaging 2015; 31(6): 1125-35. DOI: 10.1007/s10554-015-0663-5 59. D'Ascenzi F, Cameli M, Padeletti M, et al. Characterization of right atrial function and dimension in top-level athletes: A speckle tracking study. Int J Cardiovasc Imaging 2013; 29(1): 87-94. DOI: 10.1007/ s10554-012-0063-z

60. D'Ascenzi F, Pelliccia A, Natali BM, et al. Morphological and functional adaptation of left and right atria induced by training in highly trained female athletes. Circ Cardiovasc Imaging 2014; 7(2): 222-9. DOI: $10.1007 / \mathrm{s} 10554-012-0063-z$ 